\title{
Highly Diluted Acetylcholine Promotes Wound Repair in an In Vivo Model
}

\author{
Francesca Uberti, ${ }^{1, *}$ Vera Morsanuto, Sabrina Ghirlanda, \\ Sara Ruga, Nausicaa Clemente, ${ }^{2}$ Cristina Boieri, \\ Renzo Boldorini, ${ }^{3}$ and Claudio Molinari ${ }^{1}$ \\ ${ }^{1}$ Physiology Laboratory, Department of Translational Medicine, UPO, Novara, Italy. \\ ${ }^{2}$ Immunology Laboratory and ${ }^{3}$ Unit of Pathology, Department of Health Sciences, UPO, Novara, Italy.
}

Objective: Wound healing is a dynamic, interactive, and complex process that involves a series of events, including inflammation, migration, proliferation, granulation tissue formation, and matrix remodeling. Despite the high frequency of serious slow-healing wounds, there is still no adequate therapy. The aim of this study is to evaluate a new highly diluted acetylcholine (Ach) formulation obtained through a sequential kinetic activation (SKA) method applied to a wound healing in vivo model to verify the hypothesis that a low dose of Ach could be a more physiological stimulus for healing, by stimulating muscarinic and nicotinic receptors and their related intracellular pathways.

Approach: Two different concentrations ( $10 \mathrm{fg} / \mathrm{mL}$ and $1 \mathrm{pg} / \mathrm{mL})$ and two formulations (either kinetically or nonkinetically activated) of Ach were used to verify the wound healing process. Area closure, histological aspect, and nicotinic and muscarinic receptors, matrix metalloproteinase 9 (MMP-9), Nestin, and von Willebrand's factor have been assessed by Western blot or ELISA and compared to $147 \mathrm{ng} / \mathrm{mL}$ Ach, used as positive control. Moreover, the systemic effect through plasmatic radical oxygen species (ROS) production and Ach concentration has been evaluated. Results: Ach SKA $1 \mathrm{pg} / \mathrm{mL}$ revealed a significant capacity to restore the integrity of tissue compared to other formulation and this effect was more evident after a single administration.

Innovation: Topical application on skin of Ach SKA $1 \mathrm{pg} / \mathrm{mL}$ accelerates wound closure stimulating non-neuronal cholinergic system.

Conclusion: Our results demonstrate for the first time the importance in an in vivo model of highly diluted SKA Ach during wound healing, suggesting a potential use in skin disease.

Keywords: wound healing, low dose, acetylcholine, sequential kinetic activation

\section{INTRODUCTION}

THE SKIN CARRIES out multiple key functions, acting as an environmental protection barrier, an immune response site, and a neuroendocrine organ. ${ }^{1,2}$ Therefore each injury interrupting skin integrity has to be immediately repaired to restore its physiological functions. In this case the keratinocytes (KCs) proliferate

(C) Francesca Uberti et al., 2018; Published by Mary Ann Liebert, Inc. This Open Access article is distributed under the terms of the Creative Commons Attribution Noncommercial License (http:// creativecommons.org/licenses/by-nc/4.0), which permits any noncommercial use, distribution, and reproduction in any medium, provided the original authors and the source are cited.

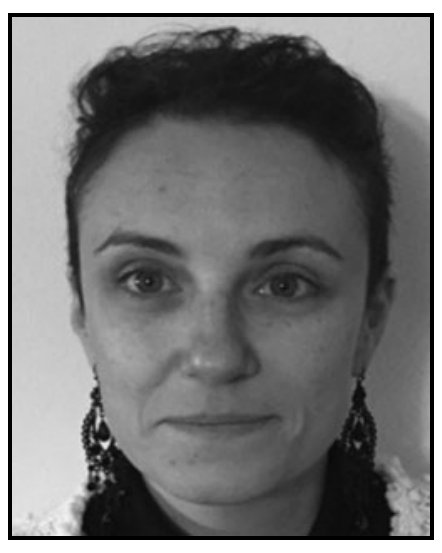

Francesca Uberti, PhD

Submitted for publication September 19 2017. Accepted in revised form November 15, 2017.

*Correspondence: Physiology Laboratory, Department of Translational Medicine, UPO, Via Solaroli 17, Novara 28100, Italy

(e-mail: francesca.uberti@med.uniupo.it). 
and migrate to reepithelialize the epidermis layer and to cover the wound while underlying fibroblasts migrate and synthesize extracellular matrix proteins for connective tissue regeneration. When a tissue injury is produced in mice, fibroblasts differentiate into myofibroblasts and promote wound healing by decreasing the size of the wound. ${ }^{3,4}$ Actually, a nonhealing wound requires a multifaceted approach with standard methods, including removal of necrotic tissue from wound, reduction of pressure on the wound, infection control, surgical revascularization, and limb elevation or compression. Currently, the most important bioactive approaches can be classified into three main categories, namely local delivery of growth factors,${ }^{5}$ delivery of therapeutic genes, ${ }^{6}$ and delivery of stem cells. ${ }^{7}$ Generally, only growth factors have been tested in large clinical trials, probably due to the safety features and logistical challenges accompanying gene or stem cell therapies. However, most growth-factor-based therapies have shown limited benefits in clinical trials for wound healing. ${ }^{8,9}$ The activity of the cholinergic receptor types can regulate inter-keratinocyte communication and extracellular matrix adhesion modifying the regulation of intercellular adhesion molecules like cadherins and integrins. ${ }^{10}$

Several important functions in $\mathrm{KC}$, including control of cell viability, proliferation, adhesion, migration, and differentiation, have been attributed to the non-neuronal cholinergic system, particularly muscarinic receptors. ${ }^{1,11,12}$ Simultaneous stimulation of nicotinic and muscarinic receptors by acetylcholine (Ach) seems to be necessary to synchronize and balance ionic and metabolic events within the cell during epidermal turnover. ${ }^{13,14}$ Some evidence has been found about the therapeutic capability of cholinomimetics or blockers in skin diseases. ${ }^{13,15,16}$ For this reason, it can be hypothesized that the role of non-neuronal Ach in KC development and functions could have important clinical implications. However, as regards the therapeutic use of Ach, it must be considered that this is a highly reactive molecule and consequently its use can lead to side effects. ${ }^{12}$

A promising way could be the use of highly diluted substances as reported by several studies. ${ }^{17,18}$ For example, highly diluted cytokines have been shown a significant beneficial effect in skin diseases both in patients and in cultured cells. ${ }^{19,20}$ Highly diluted forms used have been obtained through a preparation method called "sequential kinetic activation" (SKA) ${ }^{20,21}$; this method was also applied to prepare a new Ach formulation used to induce healing in a wound in vitro model. ${ }^{11}$ In this study low doses of sequentially kinetically activated Ach seem to play an active role in an in vitro model of wound healing, suggesting that Ach administered in a physiological range may not only be effective but also likely to be safe. The use of SKA technique is common in different fields, including pharmaceutical technology, to obtain a high therapeutic potential at very low dosages. ${ }^{11}$ Thus, the aim of this study is to evaluate the role of low doses of Ach SKA versus nonactivated diluted formulation in in vivo wound healing model.

\section{CLINICAL PROBLEM ADDRESSED}

The treatments of nonhealing wounds in many cases are ineffective, leaving patients with chronic ulcers and an enhanced risk of limb amputation. In recent years, the therapeutic capability of either cholinomimetics or blockers in pemphigus and psoriatic lesions has been suggested; so the nonneuronal Ach SKA low dose could have important clinical implications for patients with several skin disorders, including nonhealing wounds and immune and inflammatory diseases. Indeed, in preclinical studies, Ach SKA low dose is safe and effective after topical application to full-thickness wounds.

\section{MATERIALS AND METHODS}

\section{Preparation of Ach solutions}

In this study two different concentrations of Ach $(1 \mathrm{pg} / \mathrm{mL}$ and $10 \mathrm{fg} / \mathrm{mL})$ were used. These concentrations were formulated in two distinct forms named SKA and non SKA (NO SKA), based upon the knowledge of activated blends available in literature. ${ }^{22,23}$ All formulations were prepared in sterile $0.9 \%$ saline solution. The NO SKA form was a direct dilution in sterile $0.9 \%$ saline solution, whereas the SKA form was also kinetically energized by a mechanically applied force through a standardized shaking process called SKA, as previously described. ${ }^{11}$ Briefly, the applied shaking procedure is characterized by vertical shaking, a $10-\mathrm{cm}$ motion range, and a shaking speed corresponding to 100 oscillations in $10 \mathrm{~s}$. All solutions were prepared by GUNA Laboratories (GUNA S.p.a, Milan, Italy) and donated to noiVita (noiVita s.r.l.s., Novara, Italy). The effects of SKA and NO SKA have been compared to Ach $(147 \mathrm{ng} / \mathrm{mL})$, which is known to induce $\mathrm{KC}$ migration. ${ }^{11}$

\section{Animal model}

Male C57BL/6JOlaHsd mice were purchased from Envigo $^{+++}$(Bresso, Italy), $n=80$ of 8-week-old mice weighing $20-25 \mathrm{~g}$, and were used to perform wound healing experiments. The animals had free access to food and water ad libitum. The experimental sub- 
jects were kept in a single holding room and housed in a constant temperature of $21^{\circ} \mathrm{C} \pm 2^{\circ} \mathrm{C}$, humidity of $55 \% \pm 5 \%$, and under 12-h light/12-h dark cycle. During the whole period of treatment, the mice were daily monitored to assess their health status. Blood was obtained from the tail vein after inducing anesthesia. All experimental procedures on animals were reviewed and approved by the University Committee OPBA (Organismo preposto al benessere degli animali) in accordance with local ethical standards and protocols approved by national guidelines (Approval No. 108/2016-PR).

\section{Experimental design}

Before wounding procedure, mice were anesthetized with $4 \%$ isoflurane in an oxygen chamber 96\% (1 L/min) and maintained on a heating pad, to shave the dorsal area, after cleaning skin with $10 \%$ povidone-iodine (Betadine; Sigma-Aldrich, Milan, Italy), and to make the incisional wound, following a classical protocol. ${ }^{24}$ Briefly, two full-thickness wounds made by a sterile $4 \mathrm{~mm}$ diameter biopsy punch (Miltex, GmbH, Rietheim-Weilheim, Germany) on the middle of dorsal shaved skin were performed.

The wounds were surrounded by a $0.5 \mathrm{~mm}$ ring made from a thick silicone sheet with a hole in it of $5 \mathrm{~mm}$. The wound was centered within the ring which was immobilized using 6-0 nylon sutures and cyanoacrylate glue to prevent wound contraction. ${ }^{25-27} 15 \mu \mathrm{L}$ of each agent were added on the wounds and they were covered by a transparent occlusive water resistant patch. Finally, wounded mice were placed in individual cages and housed separately for the duration of the study. The animals were monitored daily for any sign of infection. The animals were randomized into two different protocols of treatment and sacrificed after 8 days ${ }^{28}$ and they were euthanized by $\mathrm{CO}_{2}$ asphyxiation at postinjury days T0 $(n=4), 5(n=12)$, and $8(n=64)$. In protocol A $(n=32)$ the animals were treated at T0, checked every $24 \mathrm{~h}$, and sacrificed after 8 days; in protocol $\mathrm{B}(n=32)$, the animals were treated every $24 \mathrm{~h}$, checked every $48 \mathrm{~h}$, and sacrificed after 8 days (protocol B). In protocol A the involvement of muscarinic and nicotinic receptors $(n=12)$ using a specific agonist and antagonist, administered for 5 days, was tested as well; in particular bethanechol ( $8 \mu \mathrm{g} / \mathrm{mL}$; Sigma-Aldrich) and scopolamine (15.21 $\mu \mathrm{g} / \mathrm{mL}$; Sigma-Aldrich) were, respectively, used as the agonist and the antagonist of muscarinic receptors. Moreover, nicotine $(8.11 \mu \mathrm{g} /$ $\mathrm{mL}$; Sigma-Aldrich) and hexamethonium (10.12 $\mu \mathrm{g} /$ $\mathrm{mL}$; Sigma-Aldrich), respectively, as the agonist and the antagonist of nicotinic receptor were ad- ministered. ${ }^{29,30}$ At the end of each treatment for each protocol, $4 \mathrm{~mm}$ diameter skin biopsy punched samples of the surrounded wound area were collected, to exclude possible circadian interferences to the outcome of the study. At the same time after treatment, blood samples were obtained and plasma was isolated to analyze radical oxygen species (ROS) production, Ach free, nestin, and matrix metalloproteinase 9 (MMP-9) concentrations in protocol A only. Two skin bioptic punches from each animal were obtained and used for the different protocols; the former was frozen in liquid nitrogen for Western blot analysis, and the latter was formalin fixed and paraffin embedded using a standard technique.

\section{Quantification of wound closure}

The pictures of the wounds at 0,5 , and 8 days were taken using Nikon D70 camera, and the areas were quantified using ImageJ program. The closure areas were compared to day 0 (area 100\% open) and to control wound (untreated). The pictures were taken at the moment of sacrifice after removing the rings. The results are expressed as percentage of the relative closure of the wounds, which was compared to the original size, using the following formula ${ }^{31}$ :

$\%$ wound closure $=\left[\left(\mathrm{WA}_{\mathrm{o}}-\mathrm{WA}\right) / \mathrm{WA}_{0} \times 100\right]$, where

$\mathrm{WA}=$ wound area;

$\mathrm{WA}_{0}=$ original size of the wound area.

\section{ROS analysis}

The concentration of ROS in plasma was measured in a 96-well plate using the Antioxidant Assay Kit (Cayman Chemical, MI) following the manufacturer's instructions. ${ }^{32}$ In brief, $10 \mu \mathrm{L}$ of metmyoglobin and $150 \mu \mathrm{L}$ of chromogen per well were added in plasma and standard samples (Trolox in Assay buffer from 0 to $0.33 \mathrm{mM}$ ) and the reactions started adding $40 \mu \mathrm{L}$ of Hydrogen Peroxide Working Solution to all the wells. The 96 -well plate was covered, mixed for 5 min at room temperature, and the absorbance was measured using spectrophotometer (VICTOR X4 Multilabel Plate Reader) at 750 or $405 \mathrm{~nm}$. The results are expressed as mean \pm standard deviation (SD) (\%).

\section{Wound extract and Western blot analysis}

At the end of each protocol the skin wounds were excised out, washed in physiological saline, weighed, cut in small pieces, and homogenized $100 \mathrm{mg}$ tissue/ $300 \mu \mathrm{L}$ with cold lysis buffer $(0.1 \mathrm{M}$ Tris, $0.01 \mathrm{M}$ $\mathrm{NaCl}, 0.025 \mathrm{M}$ EDTA, 1\% NP40, 1\% Triton X-100; 
Sigma-Aldrich, Milan, Italy) supplemented with $2 \mathrm{mM}$ sodium orthovanadate, $0.1 \mathrm{M}$ sodium fluoride (Sigma-Aldrich), 1:100 mix of protease inhibitors (Sigma-Aldrich), and 1:1,000 phenylmethylsulfonyl fluoride (PMSF; Sigma-Aldrich), using an electric potter at 1,600 rpm for $2 \mathrm{~min}$. The tissue extracts were centrifuged at $13,000 \mathrm{rpm}$ for $20 \mathrm{~min}$ at $4^{\circ} \mathrm{C}$, and the protein extracts were quantified using bicinchoninic acid (BCA) assay (Protein Assay Kit; Pierce Biotechnology, Rockford, IL). Forty micrograms of each lysate were resolved on $8 \%$ SDSPAGE gel, transferred to polyvinylidene fluoride membranes (PVDF; GE Healthcare Europe GmbH, Milan, Italy) and incubated overnight at $4^{\circ} \mathrm{C}$ with specific primary antibody: anti-muscarinic receptor 1 (M1, 1:250; Santa Cruz Biotechnology, Heidelberg, Germany), anti-muscarinic receptor 3 (M3, 1:250; Santa Cruz Biotechnology), anti-muscarinic receptor 5 (M5, 1:400; Santa Cruz Biotechnology), anti-nicotinic $\alpha 7$ (1:2,000; Sigma-Aldrich), antiMMP-9(1:2,000; Thermo-Scientific, MA), anti-von Willebrand's factor (vWF, 1:200; Santa Cruz Biotechnology), anti-CD31 (1:200; Santa Cruz Biotechnology), anti p-44/42 MAPK (1:1,000; Euroclone, Milan, Italy), and anti-ki67 (1:200; Santa Cruz Biotechnology). Protein expression was normalized and verified through $\beta$-actin detection (1:5,000; SigmaAldrich).

\section{Histological analysis}

Biopsy tissues were fixed in $10 \%$ buffered formalin at room temperature for $24 \mathrm{~h}$, dehydrated with increasing concentrations of ethanol, embedded in paraffin, cut into $5 \mu \mathrm{m}$ sections, and stained with hematoxylin and eosin (Sigma-Aldrich), to assess the morphological integrity of sample tissue. ${ }^{33}$ The stained sections were examined at light microscopy, and the pictures were taken at $200 \times$ original magnification.

\section{Ach measurements}

Choline/Ach Quantification Kit (Sigma-Aldrich) was used to determine Ach level, following the manufacturer's instructions. Briefly, the blood was centrifuged at $4,000 \mathrm{rpm}$ for $10 \mathrm{~min}$ at $4^{\circ} \mathrm{C}$ to obtain the serum fraction. Twenty microliter serum sample was mixed with $30 \mu \mathrm{L}$ of choline assay buffer and centrifuged at $13,000 \mathrm{rpm}$ for $10 \mathrm{~min} .50 \mu \mathrm{L}$ of each sample were added to $50 \mu \mathrm{L}$ of Reaction Mix into 96-well plates on a horizontal shaker for $30 \mathrm{~min}$ at room temperature protected from light. The Ach concentration was determined by measuring the absorbance through a spectrometer (VICTOR X3 Multilabel Plate Reader) at $570 \mathrm{~nm}$ and calculated by comparing results to choline standards $(0-5 \mathrm{nmol})$.

\section{Nestin quantification assay}

Mouse NES (Nestin) ELISA Kit (Cabru, Italy) was used to quantify nestin on serum samples, following the manufacturer's instructions. Briefly, serum collected from blood samples was added in 96-well/plate and incubated for $90 \mathrm{~min}$ at $37^{\circ} \mathrm{C}$. Then biotinylated antibody and SABC working solution were added and incubated for 60 and $30 \mathrm{~min}$, respectively, at $37^{\circ} \mathrm{C} .3,3^{\prime}, 5,5^{\prime}$-tetramethylbenzidine (TMB) substrate, after incubation for $30 \mathrm{~min}$ at $37^{\circ} \mathrm{C}$, and Stop solution were added in the plate. Nestin concentration was determined by measuring the absorbance through a spectrometer (VICTOR X3 Multilabel Plate Reader) at $450 \mathrm{~nm}$ and calculated by comparing results to nestin standard curve.

\section{MMP-9 quantification assay}

MMP-9 (Mouse) ELISA Kit(DBA, Italy) was used to quantify MMP-9 on serum samples, following the manufacturer's instructions. Briefly, serum samples in 96 -well/plate were incubated at $37^{\circ} \mathrm{C}$ for 90 min and then biotinylated antibody and ABC working solution were added and the plate incubated at $37^{\circ} \mathrm{C}$ for 60 and $30 \mathrm{~min}$, respectively.

TMB substrate, after incubation for $15 \mathrm{~min}$ at $37^{\circ} \mathrm{C}$, and TMB Stop solution were added. The MMP-9 concentration was determined by measuring the absorbance through a spectrometer (VICTOR X3 Multilabel Plate Reader) at $450 \mathrm{~nm}$ and calculated by comparing results to MMP-9 standard curve.

\section{Statistical analysis}

All results were analyzed by one-way analysis of variance (ANOVA) followed by Bonferroni post hoc test; data are expressed as mean $\pm \mathrm{SD}$ of at least three independent experiments for each experimental protocol. The percentage values were compared through Mann-Whitney $U$ test. Comparisons between the two groups were performed using a twotailed Student's $t$-test. Multiple comparisons between groups were analyzed by two-way ANOVA followed by a two-sided Dunnett post hoc testing. $p$-Value $<0.05$ was considered statistically significant.

\section{RESULTS}

\section{Evaluation of wound healing area}

The wound healing experimental model performed in mice treated lasted 8 days using different formulations of Ach (SKA and NO SKA) in two different concentrations $(10 \mathrm{fg} / \mathrm{mL}$ and $1 \mathrm{pg} / \mathrm{mL})$. Data were compared to Ach $147 \mathrm{ng} / \mathrm{mL}$ to study the ability of Ach low doses to induce the closure of wound area. As reported in Fig. 1, there were no substantial differences between protocol A and B 
A

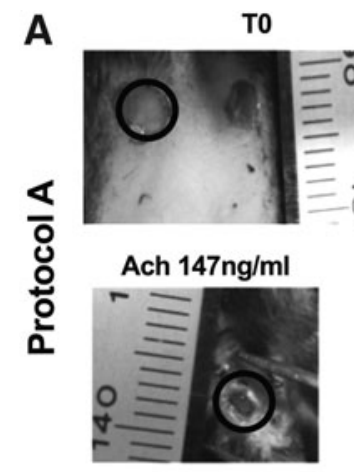

Control

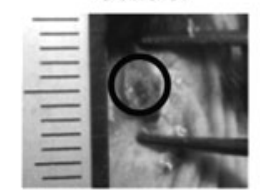

Solvent SKA

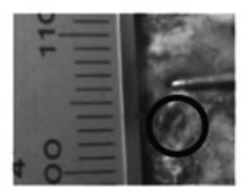

Ach $10 \mathrm{fg} / \mathrm{ml}$ SKA Ach $10 \mathrm{fg} / \mathrm{ml}$ NO SKA
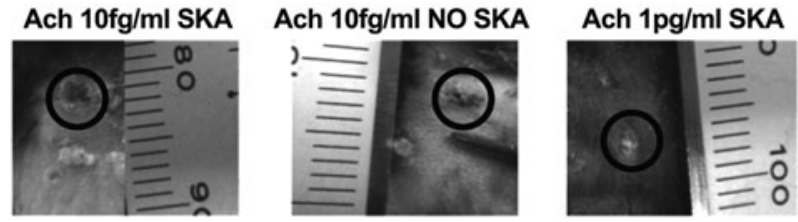

$\longrightarrow$

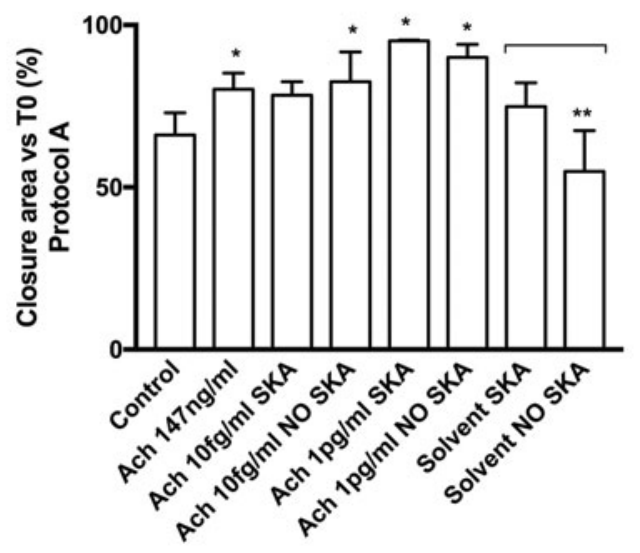

B

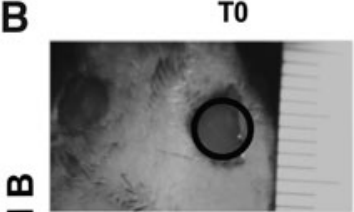

응

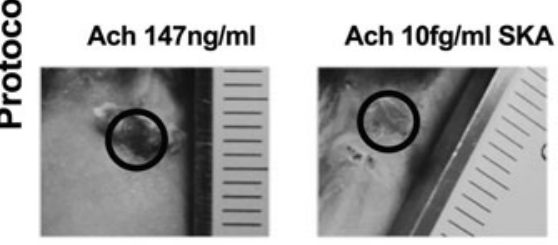

Control

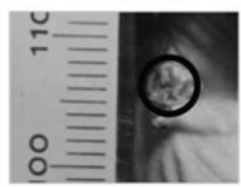

Solvent SKA

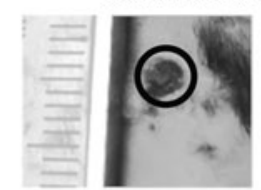

Solvent NO SKA

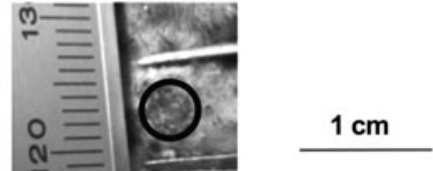

Ach 1pg/ml NO SKA

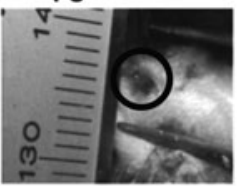

Solvent NO SKA
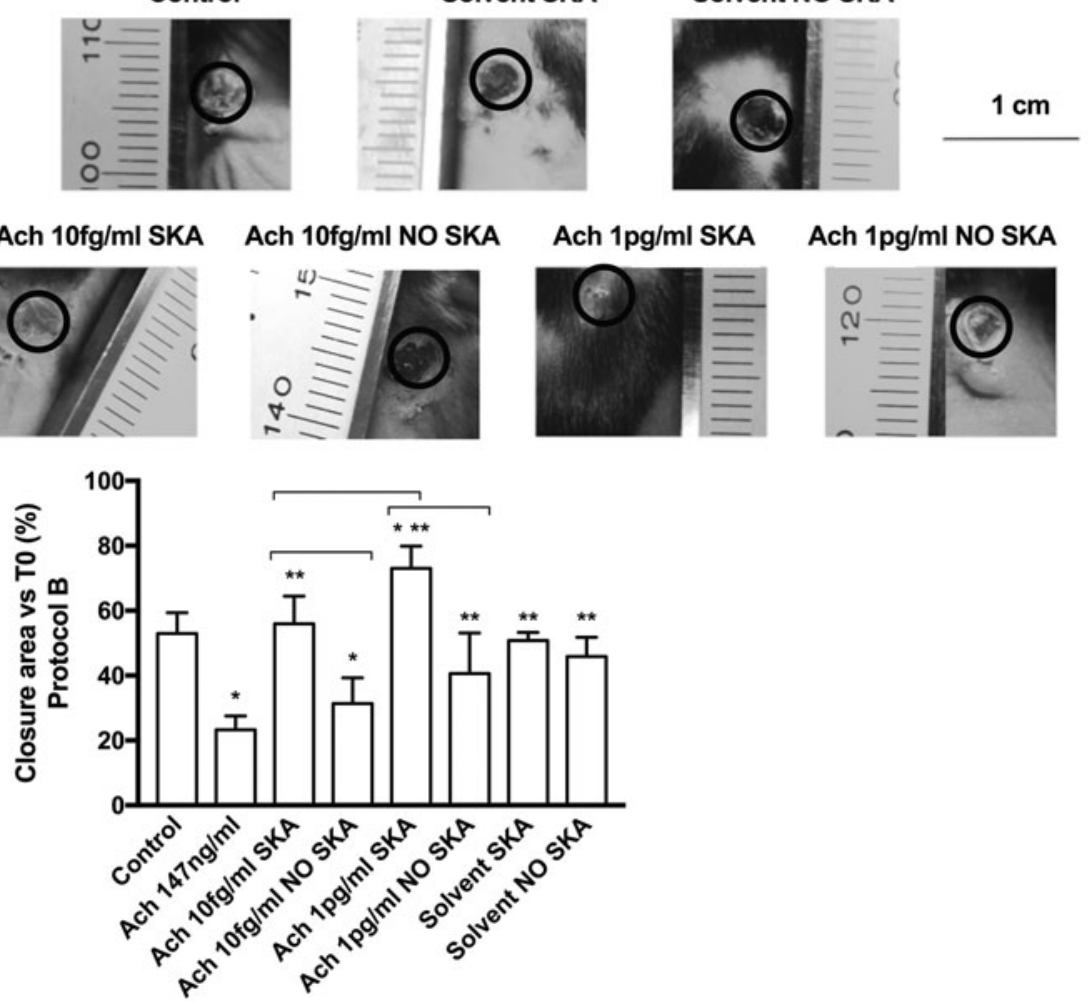

Figure 1. Wound healing postsurgical measurements and relative wound closure graph. On both panels the quantification area of wound that may be considered as open/partially open after treatments is shown. (A) Data obtained in protocol A of treatment (8 days with one administration) are reported; (B) data obtained in presence of protocol B (8 days with one administration/day) are shown. Scale bar, $1 \mathrm{~cm}$ for all images and the black circle corresponds to the original area. ${ }^{*} p<0.05$ versus control, ${ }^{* *} p<0.05$ versus Ach $147 \mathrm{ng} / \mathrm{mL}$, bars $(p<0.05)$ indicate significance between the activated and nonactivated forms. The results are expressed as mean \pm SD (\%) compared to TO ( $n=32$ for each protocol). Ach, acetylcholine; NO SKA, nonsequential kinetic activation; SKA, sequential kinetic activation; SD, standard deviation. 
in the eschar formation, although it appeared at a starting phase in protocol $\mathrm{B}$ and more mature during protocol $\mathrm{A}$. In addition, in protocol $\mathrm{A}$, the Ach SKA $1 \mathrm{pg} / \mathrm{mL}$ was able to induce a greater closure area than what was observed with the NO SKA form (44\% and $33 \%$ vs. control, respectively) and compared to $147 \mathrm{ng} / \mathrm{mL}$ Ach (about 20\%) as well. This effect was also statistically significant $(p<0.05)$ in comparison with untreated wounds and to the solvent alone. In protocol B (Fig. 1B) the presence of Ach SKA $1 \mathrm{pg} / \mathrm{mL}$ was able to induce a faster closure than control (about 37\%), the NO SKA $1 \mathrm{pg} / \mathrm{mL}$ (about $82 \%$ ), the Ach $10 \mathrm{fg} / \mathrm{mL}$ both SKA (about
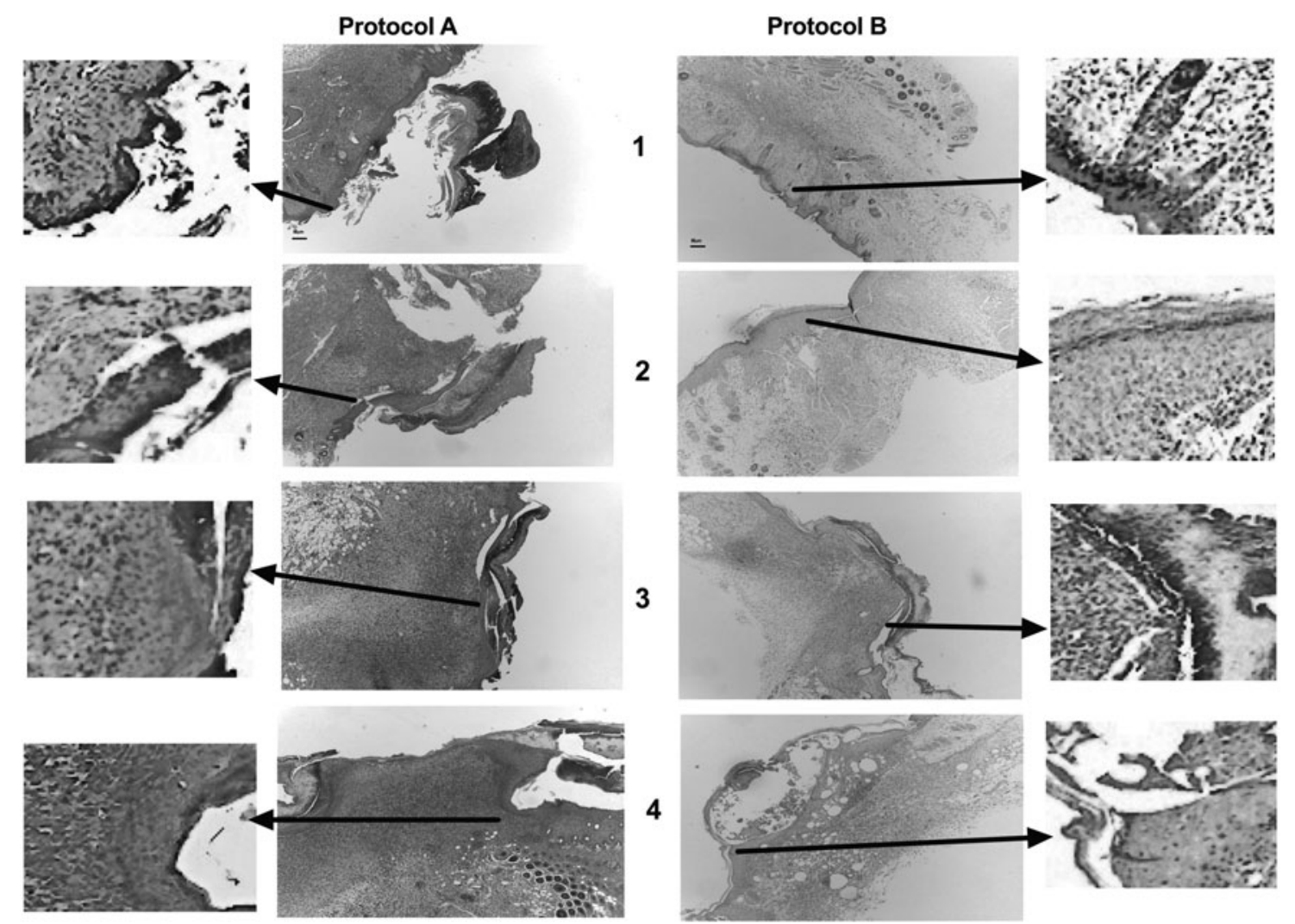

$31 \%$ ) and NO SKA (about 128\%), respectively. However, Ach SKA $1 \mathrm{pg} / \mathrm{mL}$ was able to exert a greater effect in protocol A than in B (30\% protocol A vs. protocol B). Indeed, Ach SKA $1 \mathrm{pg} / \mathrm{mL}$ appears to induce an almost or fully complete healing demonstrating the importance of dilution and SKA. In both protocols Ach $147 \mathrm{ng} / \mathrm{mL}$ was not able to restore the structural integrity of the damaged area. These findings have been confirmed by morphological analysis (Fig. 2), in which Ach SKA $1 \mathrm{pg} / \mathrm{mL}$ seems to be a better choice. In protocol $A$ the mice treated with Ach SKA $1 \mathrm{pg} / \mathrm{mL}$ presented a complete epithelialization (shown within circle) of the wound
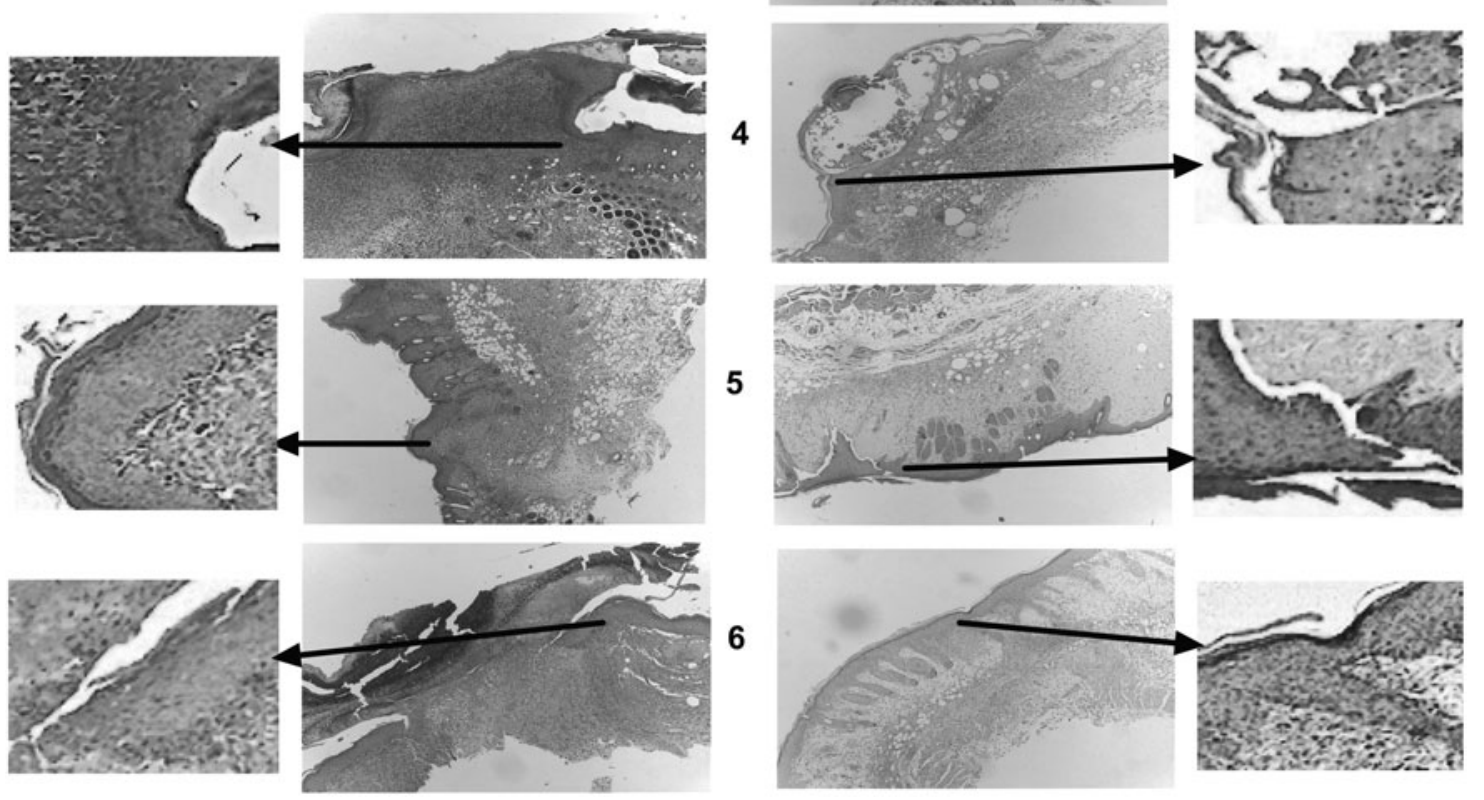

Figure 2. Hematoxylin and eosin stained and sectioned mouse wound tissue. Representative microscopy pictures of wound healing with each treatment with protocol $\mathrm{A}(n=18)$ and protocol $\mathrm{B}(n=18)$ are reported at original magnification of $200 \times$ and are the representative examples. The scale reported is to be considered valid for all treatments. 1 = control; $2=$ Ach $147 \mathrm{ng} / \mathrm{mL} ; 3=$ Ach $10 \mathrm{fg} / \mathrm{mL} \mathrm{SKA} ; 4=$ Ach $10 \mathrm{fg} / \mathrm{mL}$ NO SKA; $5=$ Ach 1 pg/mL SKA; $6=$ Ach 1 pg/mL NO SKA. 
compared to control, to the same NO SKA form, to the Ach $10 \mathrm{fg} / \mathrm{mL}$ both SKA and NO SKA, respectively. In particular, epithelialization appeared without any ulcer, with the presence of inactive granulation tissue, with collagen remodeling and angiogenesis; for this reason it is possible to envisage a restitutio ad integrum. The same concentration in NO SKA showed poor capacity to heal wound, limited to an initial state, and appearing ulcerated. Ach SKA $10 \mathrm{fg} / \mathrm{mL}$ was different from Ach SKA $1 \mathrm{pg} / \mathrm{mL}$ because the granulation tissue was still very active with a superficial ulceration; the same NO SKA concentration induced a condition similar to SKA $10 \mathrm{fg} / \mathrm{mL}$, but the ulceration was more extensive. In contrast, in all treatments of protocol B (Fig. 2), the granulation tissue seemed to be still very active, and the healing was at an early stage. In particular, Ach SKA $1 \mathrm{pg} / \mathrm{mL}$ showed a quite evident capacity to repair wound; reepithelialization was almost complete, but in the underlying layer fibroblasts, sclerosis, and granulation tissue were still present. Finally, another important finding was obtained from Ach $147 \mathrm{ng} / \mathrm{mL}$ administration in both protocols; in particular only in protocol A an initial remodeling compared to control was observed, confirming the importance of Ach dosage.

\section{Involvement of MMP-9, vWF, nestin,} and muscarinic and nicotinic receptors

To determine whether there was an involvement of nicotinic and muscarinic receptors in healing, specific agonists and antagonists were tested in protocol A. As reported in Fig. 3 bethanechol $(8 \mu \mathrm{g} / \mathrm{mL}$; M1 and M5 agonist) and nicotine $(8.11 \mu \mathrm{g} / \mathrm{mL} ; \alpha 7$ agonist) did not induce any significant changes compared to control $(p>0.05)$ on the damaged area. Scopolamine $(15.21 \mu \mathrm{g} / \mathrm{mL} ; \mathrm{M} 1$ antagonist) and hexamethonium $(10.12 \mu \mathrm{g} / \mathrm{mL} ; \alpha 3 \beta 2$ antagonist)
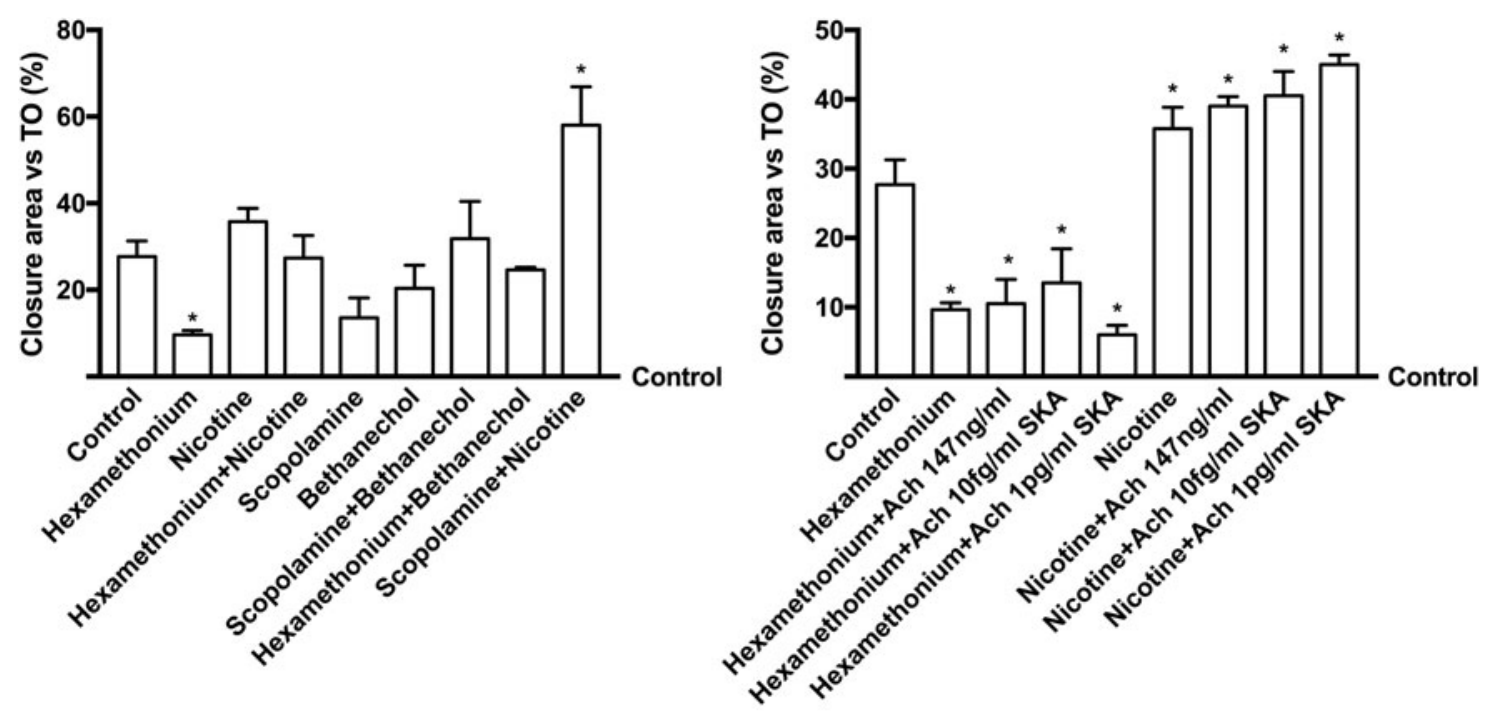

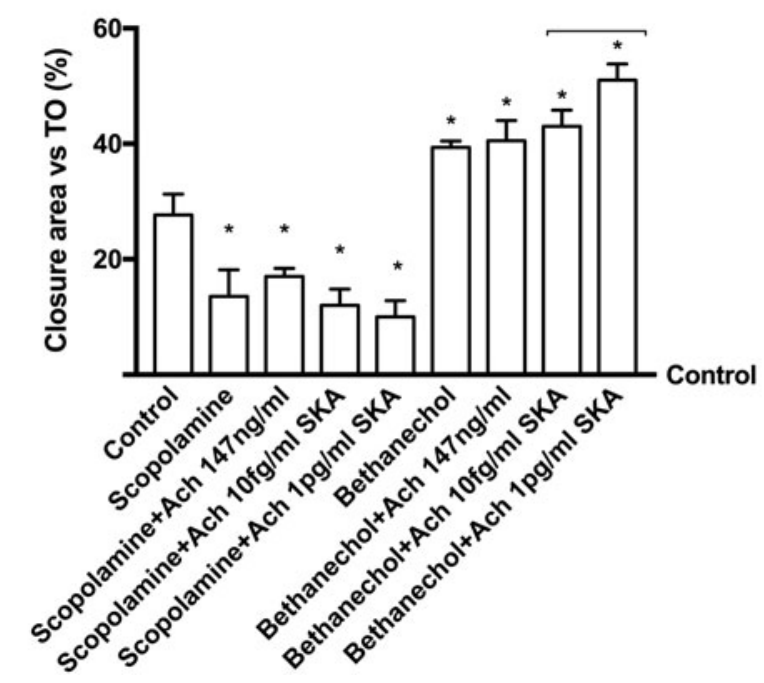

Figure 3. Representative wound closure graph of anticholinergic drugs performed in protocol A. The results are expressed as mean \pm SD $(n=12) .{ }^{*} p<0.05$ versus control, bars $(p<0.05)$ indicate significance between agonistic and antagonist agents. 
prevented any physiological healing compared to control (50\% and 64\%, respectively). Using both agonist and antagonist combined together, a significant reduction in healing was observed $(p<0.05)$ compared to control, confirming the active role of M1, M3, and $\alpha 7$. For this purpose, in the subsequent experiments the effects of different formulations of Ach on these receptors were also investigated. The involvement of these receptors on Ach mechanisms was also confirmed by the analysis of experiments performed in presence of Ach $147 \mathrm{ng} / \mathrm{mL}$ and Ach SKA ( $10 \mathrm{fg} / \mathrm{mL}$ and $1 \mathrm{pg} / \mathrm{mL})$.
As shown in Figs. 4 and 5, the importance of the involvement of the M1, M3, and $\alpha 7$ receptors in both protocols was clarified by Western blot and densitometric analysis, and the best results were obtained with protocol A. In particular in protocol A (Fig. 4), in presence of Ach SKA $1 \mathrm{pg} / \mathrm{mL}$ the M1 and M3 expressions were more evident compared to control (73\% and 55\%, respectively), to Ach SKA $10 \mathrm{fg} / \mathrm{mL}$, and compared to both NO SKA concentrations $(p<0.05)$. In addition Ach SKA $1 \mathrm{pg} / \mathrm{mL}$ was able to enhance the expression of $\alpha 7$ compared to control (about 81\%), confirming the link among M1, M3, and $\alpha 7$ receptors in healing. On the
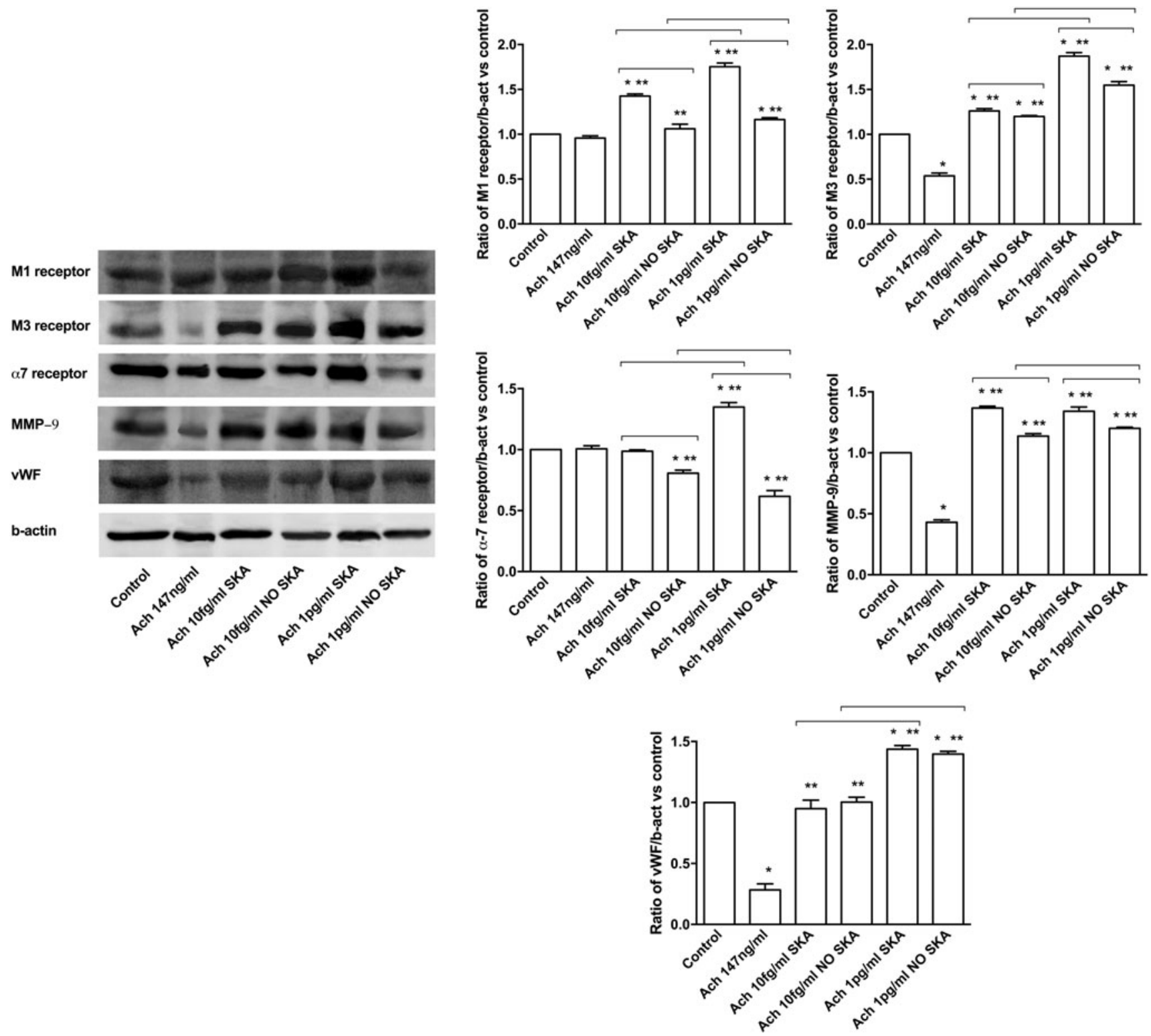

Figure 4. Western blot and densitometric analysis of muscarinic receptors (M1 and M3), nicotinic ( $\alpha 7)$ receptor, MMP-9, and vWF markers in protocol A. Protein extracts were analyzed by immunoblotting with specific antibodies against the indicated proteins and normalized through $\beta$-actin detection. Data are expressed as mean \pm SD $(\%)$ of four biological replicates normalized to control values. The pictures are examples for each treatment of the experimental protocol. ${ }^{*} p<0.05$ versus control, ${ }^{* *} p<0.05$ versus Ach $147 \mathrm{ng} / \mathrm{mL}$, bars $(p<0.05)$ indicate significance between the activated forms, the nonactivated forms, and between the two different forms. MMP-9, matrix metalloproteinase 9; vWF, von Willebrand's factor. 

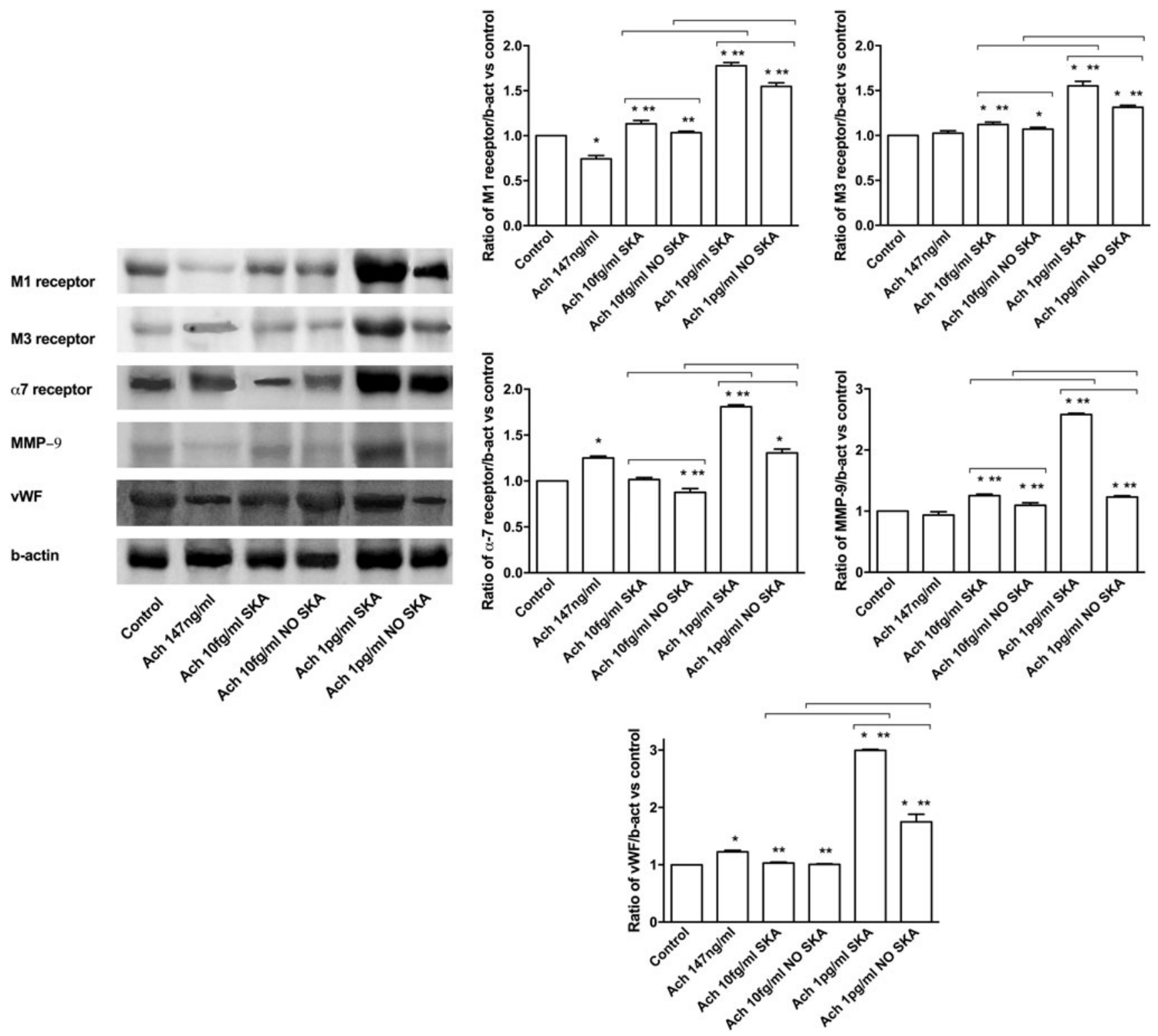

Figure 5. Western blot and densitometric analysis of muscarinic receptors (M1 and M3), nicotinic ( $\alpha 7$ ) receptor, MMP-9, and vWF markers in protocol B. Protein extracts were analyzed by immunoblotting with specific antibodies against the indicated proteins and normalized through $\beta$-actin detection. Data are expressed as mean \pm SD (\%) of four biological replicates normalized to control values. The pictures are an example of each treatment of the experimental protocol. ${ }^{*} p<0.05$ versus control, ${ }^{* *} p<0.05$ versus Ach $147 \mathrm{ng} / \mathrm{mL}$, bars $(p<0.05)$ indicate significance between the activated forms, the nonactivated forms, and between the two different forms.

contrary, in protocol B (Fig. 5) Ach SKA $10 \mathrm{fg} / \mathrm{mL}$ and $1 \mathrm{pg} / \mathrm{mL}$ were able to induce M1 and M3 expressions compared to control ( $10 \mathrm{fg} / \mathrm{mL}: 43 \% \mathrm{M} 1$, 26\% M3; $1 \mathrm{pg} / \mathrm{mL}: 75 \% \mathrm{M} 1,87 \% \mathrm{M} 3$ ), and Ach SKA $1 \mathrm{pg} / \mathrm{mL}$ enhanced the expression of $\alpha 7$ receptor of about $35 \%$ compared to control. In both protocols Ach $10 \mathrm{fg} / \mathrm{mL}$ and $1 \mathrm{pg} / \mathrm{mL}$ NO SKA was effective only on the M1 and M3 receptors. Finally, Ach $147 \mathrm{ng} / \mathrm{mL}$ was not able to induce expression of receptors in a sufficient manner to generate healing.

MMP-9 and vWF were also analyzed in both protocols; as reported in Figs. 4 and 5, Ach SKA was able to act early on healing, in particular, on for- mation of cell matrix and on adhesion in lesion area. In particular, in protocol A both Ach $10 \mathrm{fg} / \mathrm{mL}$ and $1 \mathrm{pg} / \mathrm{mL}$ SKA forms $(p<0.05)$ appeared to be more effective than control to act on the collagen remodeling (eschar formation, late stage of healing), using the MMP-9 marker, and compared to Ach NO SKA; in protocol B both concentrations of Ach SKA caused an increase of MMP-9 compared to control $(36 \% 10 \mathrm{fg} / \mathrm{mL} ; 34 \% 1 \mathrm{pg} / \mathrm{mL})$ and to the same NO SKA forms ( $10 \mathrm{fg} / \mathrm{mL} 13 \% ; 1 \mathrm{pg} / \mathrm{mL} 20 \%)$. Finally, as regards the terminal stages of healing, Ach SKA was able to complete the healing process acting on angiogenesis, as assessed by the 
A
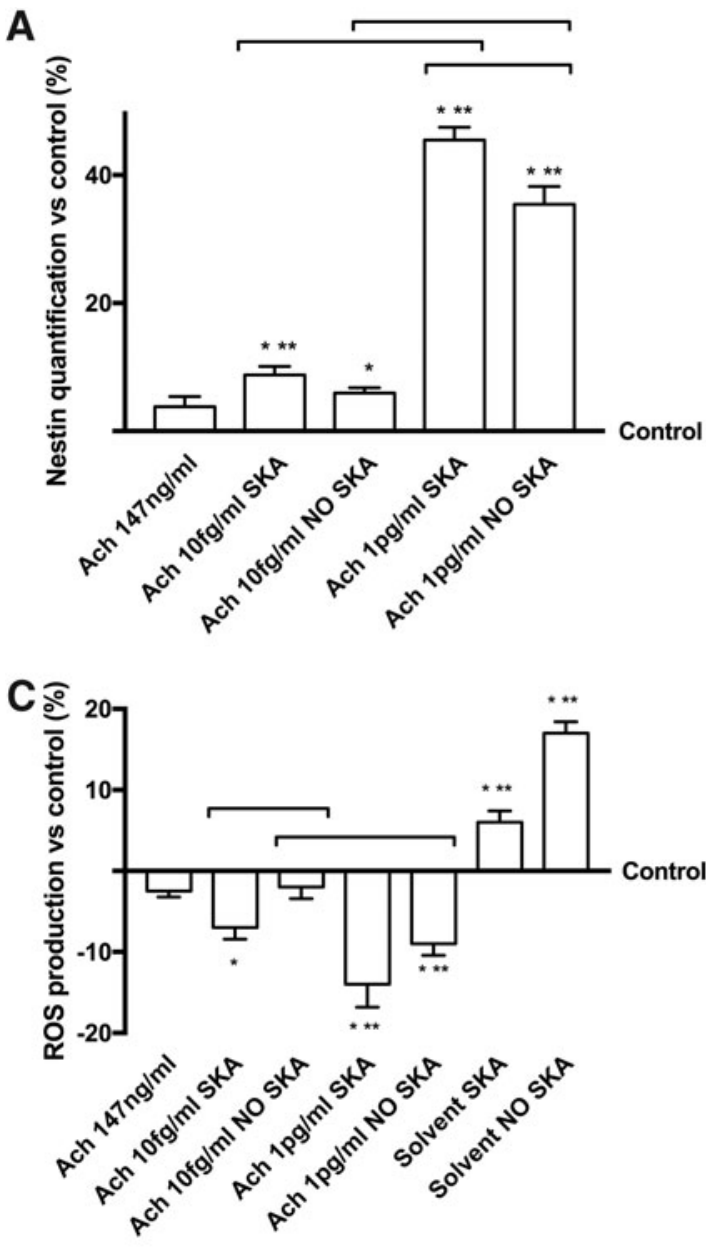

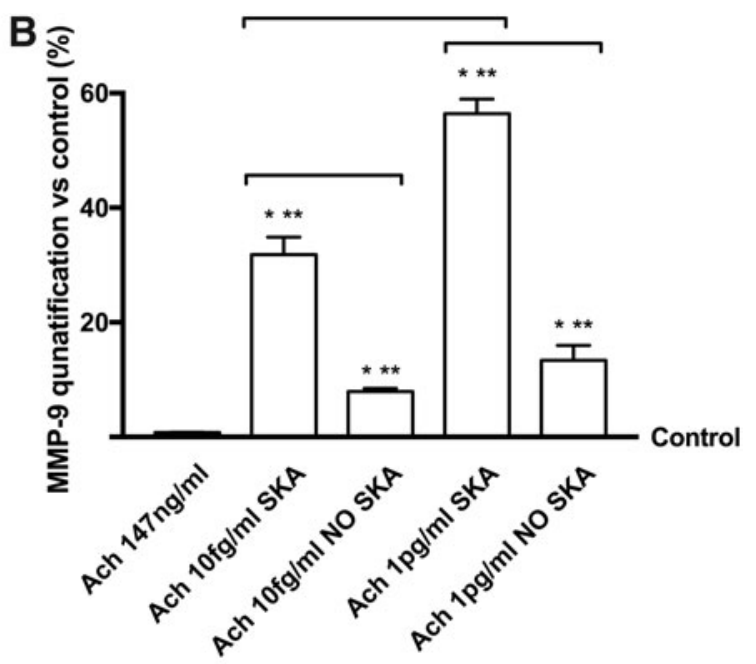

D

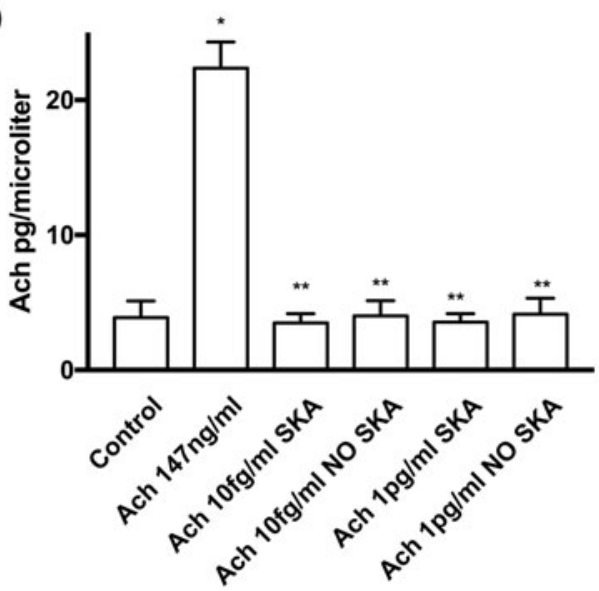

Figure 6. Analysis of systemic nestin, MMP-9, ROS, and Ach quantification level with protocol A. (A) Nestin activity is expressed as mean \pm SD (\%) of eight biological replicates normalized to control values and indicated as a percentage respect to the control. (B) MMP-9 activity is expressed as mean \pm SD (\%) of eight biological replicates normalized to control values and indicated as a percentage with respect to the control. (C) ROS production is expressed as mean \pm SD (\%) of eight biological replicates normalized to control values and indicated as percentage with respect to the control. (D) Ach quantification is expressed as mean \pm SD (\%) of eight biological replicates normalized to control values. ${ }^{*} p<0.05$ versus control, ${ }^{* *} p<0.05$ versus Ach $147 \mathrm{ng} / \mathrm{mL}$, bars ( $p<0.05$ ) indicate significance between the activated forms, the nonactivated forms, and between the two different forms. ROS, radical oxygen species.

study on marker vWF (involved in new blood vessels). In particular, in protocols both $\mathrm{A}$ and $\mathrm{B}$, only Ach SKA $1 \mathrm{pg} / \mathrm{mL}$ was able to enhance vWF production $(p<0.05)$ compared to control. In addition, as reported in Fig. 6, the activities of nestin (Fig. 6A) and MMP-9 (Fig. 6B) activities were analyzed on plasma samples in protocol A since this appeared as the most effective protocol. Ach SKA forms showed a greater increase in MMP-9 compared to control $(p<0.05)$, and, in particular, a significant increase was observed in presence of Ach SKA $1 \mathrm{pg} / \mathrm{mL}$ compared to the Ach SKA $10 \mathrm{fg} / \mathrm{mL}(p<0.05)$ and Ach $147 \mathrm{ng} / \mathrm{mL}(p<0.05)$, following previous data about the remodeling of the matrix. In addition, the activity of nestin, the neoangiogenesis marker, confirmed the hypothesis about the vascularization; indeed Ach SKA $1 \mathrm{pg} / \mathrm{mL}$ induced a significant increased activity of nestin compared to control $(p<0.05)$ and Ach $147 \mathrm{ng} / \mathrm{mL}(p<0.05)$ and $10 \mathrm{fg} /$ mL SKA $(p<0.05)$. These data support the results observed with morphological analysis. These results showed an active role of Ach SKA $1 \mathrm{pg} / \mathrm{mL}$ in migration, healing, and angiogenesis and proved that the single treatment was the most effective. Therefore, the final analysis will be performed using protocol A only.

\section{ROS analysis and Ach quantification}

The plasmatic production of ROS during healing is a physiological process. However, their levels should be kept low, otherwise beneficial effects would turn into cytotoxic. As reported in Fig. 6A, in presence of Ach SKA $1 \mathrm{pg} / \mathrm{mL}$ the level of ROS was less than control $(p<0.05)$, as well as it was 
compared to other Ach forms $(p<0.05)$, confirming its active role. Ach $147 \mathrm{ng} / \mathrm{mL}$ did not induce an excessive release of ROS, thus providing a positive condition to begin the healing process. Both Ach SKA and NO SKA $1 \mathrm{pg} / \mathrm{mL}$ kept levels of ROS lower than Ach $147 \mathrm{ng} / \mathrm{mL}(p<0.05)$. In addition to exclude a systemic effect of Ach, the analysis on its plasma concentration during protocol A was also performed (Fig. 6B). Both Ach SKA and NO SKA did not increase the plasma Ach concentration, and the differences among results obtained with different forms and concentrations were not significant. On the contrary Ach $147 \mathrm{ng} / \mathrm{mL}$ significantly increased the circulating amount of Ach and it could cause a systemic effect (about 470\% compared to control). The treatments with both concentrations of Ach SKA and NO SKA were not able to act systemically, since plasma concentration remained unvaried.

\section{DISCUSSION}

Poor wound healing after trauma, surgery, acute illness, or chronic diseases affects millions of people worldwide each year, and current therapies have limited effectiveness. ${ }^{34}$ The aim of this study was to examine the possible use of low-dose Ach SKA as an innovative therapy for the stimulation of nonneuronal cholinergic system in healing. The effectiveness of low doses of cytokines is well known by a study on asthmatic mice, ${ }^{17}$ and in many clinical studies, for example, they were used as supportive care or as pain relief in cancer patients, ${ }^{35,36}$ or to reduce symptoms in patients with psoriasis or vitiligo. ${ }^{19,21,37,38}$ Further data have also shown the improvements in patients with cutaneous mucus diseases treated with cholinergic agents. ${ }^{39}$ In this context it was important to demonstrate in an in vivo model the ability of low-dose Ach SKA during healing, suggesting a potential use in dermatology. Ach is produced in all types of living cells and it is greatly abundant on surface epithelium, ${ }^{15}$ in particular in the human skin (i.e., Ach $1,000 \mathrm{pmol} / \mathrm{g}$ ) where it is synthesized by choline acetyltransferase and hydrolyzed by acetylcholinesterase. ${ }^{40} \mathrm{~A}$ single KC synthesizes an average of $2 \times 10^{-17} \mathrm{~mol}$ of Ach and gives $7 \times 10^{-19} \mathrm{~mol} / \mathrm{min} .{ }^{13}$ This finding accounts for the dosage of Ach SKA used in this study and allows us to consider the concentrations as physiological ( $10 \mathrm{fg} / \mathrm{mL}$ and $1 \mathrm{pg} / \mathrm{mL}$ ). Reepithelialization is an Ach-dependent process mediated by muscarinic and nicotinic receptors. Both in vitro ${ }^{11}$ and in vivo studies showed the ability of Ach SKA $1 \mathrm{pg} / \mathrm{mL}$ and Ach SKA $10 \mathrm{fg} / \mathrm{mL}$ to act on both muscarinic (particularly M1 and M3) and nicotinic receptors $(\alpha 7)$. Two different protocols of treatment were used to assess the best posology in an in vivo model of wound. In particular, protocol A was characterized by a single stimulation, whereas protocol B consisted of repeated administrations every $24 \mathrm{~h}$.

Data observed showed that protocol A had greater effectiveness than protocol B and that Ach SKA $1 \mathrm{pg} / \mathrm{mL}$ was able to repair lesion more rapidly than Ach SKA $10 \mathrm{fg} / \mathrm{mL}$. We investigated the closure area, the intracellular mechanism activated, the ROS produced, and the eventual systemic effect of low dose Ach. An important element was the role of muscarinic and nicotinic receptors. Data obtained in the in vivo model on muscarinic/nicotinic receptors showed that ultra-diluted Ach acts through the same mechanisms activated by Ach $147 \mathrm{ng} / \mathrm{mL}$, which supports the hypothesis of beneficial effects exerted by the low dose in the absence of adverse side effects (such as oxidative stress) as reported by low levels of ROS concentration observed in plasma samples.

Hence the modulation of receptor activity can be hypothesized; in both protocols $\mathrm{M} 1$ and $\alpha 7$ receptors acted in a decoupled way (M1 increasing, while $\alpha 7$ decreasing) and M3 and $\alpha 7$ receptors acted in a coupled way (increasing together). This can be seen in the treatment with SKA $1 \mathrm{pg} / \mathrm{mL}$ in protocol A. Moreover, the treatment with Ach $147 \mathrm{ng} / \mathrm{mL}$ in the two protocols demonstrated the dose limit in wound; in protocol B Ach $147 \mathrm{ng} / \mathrm{mL}$ was not able to start healing (migration), but in protocol A healing began and continued in the later stages of migration, as shown by molecular markers (vWF and MMP-9 and nestin). The SKA forms (1 pg/mL and $10 \mathrm{fg} / \mathrm{mL}$ ) showed a greater ability to trigger healing compared to Ach $147 \mathrm{ng} / \mathrm{mL}$ and these effects were more evident in the presence of a single treatment (protocol A).

The evaluation of vWF, MMP-9, and nestin was important to understand whether the healing process has fully started leading to a restitutio ad integrum or it was just at the initial steps. Data from this study demonstrate for the first time that Ach SKA $1 \mathrm{pg} / \mathrm{mL}$ was able to activate all stages of healing effectively when administered only once (protocol A) compared to the same concentration of NO SKA, to Ach SKA $10 \mathrm{fg} / \mathrm{mL}$, and to Ach $147 \mathrm{ng} / \mathrm{mL}$, respectively. In addition, Ach SKA $1 \mathrm{pg} / \mathrm{mL}$ was able to reduce and maintain the level of ROS at a basal concentration and did not induce any significant changes on Ach concentration in blood, confirming that the beneficial effects observed had no negative systemic effects. These data demonstrate for the first time an in vivo model that low doses of Ach could be important for the development of new 
therapeutic strategies for wound healing. In addition these findings suggest that the cholinergic agents could have a large potential use in dermatology. The observation of an increased effect induced by Ach SKA has been demonstrated for the first time in vivo model within the nonneuronal cholinergic system.

\section{KEY FINDINGS}

- Topical application of low-dose Ach SKA heals full-thickness cutaneous wounds stimulating non-neuronal cholinergic system.

- Low-dose Ach SKA promotes angiogenesis and migration of KC, through the balance between nicotinic and muscarinic receptors.

- Preclinical data confirmed that Ach SKA at low doses is safe, effective, and represents an alternative solution for the treatment of wounds.

\section{INNOVATION}

Ach SKA low doses for topical treatment of both nonhealing/healing or acute/chronic cutaneous wounds may be an innovative therapeutic strategy. Ach SKA can be safe for topical administration without either systemic or adverse effects. A single administration of Ach SKA could easily and rapidly restore epithelium, thus it may represent a convenient therapeutic strategy for patients with relatively low costs.

\section{ACKNOWLEDGMENTS AND FUNDING SOURCES}

The authors thank Ms. Mariangela P. Fortunato for her help with language revision. GUNA S.p.a (Vincenzo Miranda) contributed donating solutions. Work was supported by private funding of Physiology laboratory and by Fondazione Giovanni Goria and Fondazione CRT “2015.”

\section{AUTHOR DISCLOSURE AND GHOSTWRITING}

No ghostwriting was involved, and there are no disclosures related to any author.

\section{ABOUT THE AUTHORS}

Francesca Uberti, PhD, is a post doc and Professor of General Pathology and has supervised funded research on use of Ach SKA for the treatment of wounds. She is a co-founder and CEO \& CTO of start-up spin-off "noiVita srls" at University of Eastern Piedmont. Claudio Molinari, MD, works at the Physiology Laboratory. Vera Morsanuto, MS, is a PhD student at Physiology Laboratory. Sabrina Ghirlanda, MS, and Sara Ruga, BS, are the Master students in Biotechnology at Physiology Laboratory. Nausicaa Clemente, PhD, is a postdoc in Immunology Laboratory. Cristina Boieri, MS, is a member of the unit of Pathology directed by Prof. Renzo Boldorini, MD.

\section{REFERENCES}

1. Kurzen H, Wessler I, Kirkpatrick CJ, Kawashima K Grando SA. The non-neuronal cholinergic system of human skin. Horm Metab Res 2007;39:125-135.

2. Slominski AT, Zmijewski MA, Skobowiat C, Zbytek B, Slominski RM, Steketee JD. Sensing the environment: regulation of local and global homeostasis by the skin's neuroendocrine system. Adv Anat Embryol Cell Biol 2012;212:v, vii, 1-115.

3. Gurtner GC, Werner S, Barrandon Y, Longaker MT Wound repair and regeneration. Nature 2008;453: 314-321

4. Jain N, Kalailingam P, Tan KW, Tan HB, Sng MK, Chan JS, et al. Conditional knockout of N-WASP in mouse fibroblast caused keratinocyte hyper proliferation and enhanced wound closure. Sci Rep 2016;6:38109.

5. Goldman R. Growth factors and chronic wound healing: past, present, and future. Adv Skin Wound Care 2004;17:24-35

6. Branski LK, Pereira CT, Herndon DN, Jeschke MG. Gene therapy in wound healing: present status and future directions. Gene Ther 2007:14:1-10.
7. Zahorec P, Koller J, Danisovic L, Bohac M. Mesenchymal stem cells for chronic wounds therapy. Cell Tissue Bank 2015;16:19-26.

8. Buchberger B, Follmann M, Freyer D, Huppertz $H$, Ehm A, Wasem J. The evidence for the use of growth factors and active skin substitutes for the treatment of non-infected diabetic foot ulcers (DFU): a health technology assessment (HTA). Exp Clin Endocrinol Diabetes 2011;119:472-479.

9. Später T, Frueh FS, Metzger W, Menger MD, Laschke MW. In vivo biocompatibility, vascularization, and incorporation of Integra ${ }^{\circledR}$ dermal regenerative template and flowable wound matrix. J Biomed Mater Res B Appl Biomater 2016;106:52-60.

10. Fania L, Zampetti A, Guerriero G, Feliciani C. Alteration of cholinergic system in keratinocytes cells produces acantholysis: a possible use of cholinergic drugs in pemphigus vulgaris. Antiinflamm Antiallergy Agents Med Chem 2012;11:238-242.

11. Uberti F, Bardelli C, Morsanuto V, Ghirlanda S, Cochis $\mathrm{A}$, Molinari $\mathrm{C}$. Stimulation of the nonneuronal cholinergic system by highly diluted acetylcholine in keratinocytes. Cells Tissues Organs 2016;203 215-230.

12. Beck B, Zholos A, Sydorenko V, Roudbaraki M, Lehen'kyi V, Bordat P, et al. TRPC7 is a receptoroperated DAG-activated channel in human keratinocytes. J Invest Dermatol 2006;126:1982-1993.

13. Grando SA, Kist DA, Qi M, Dahl MV. Human keratinocytes synthesize, secrete, and degrade acetylcholine. J Invest Dermatol 1993;101:32-36.

14. Grando SA, Pittelkow MR, Schallreuter KU. Adrenergic and cholinergic control in the biology of epidermis: physiological and clinical significance. J Invest Dermatol 2006;126:1948-1965.

15. Grando SA. Cholinergic control of epidermal cohesion. Exp Dermatol 2006;15:265-282.

16. Grando SA. Pemphigus autoimmunity: hypotheses and realities. Autoimmunity 2011;45:7-35.

17. Gariboldi S, Palazzo M, Zanobbio L, Dusio GF Mauro V, Solimene U, et al. Low dose oral administration of cytokines for treatment of allergic asthma. Pulm Pharmacol Ther 2009;22:497-510. 
18. D'Amico L, Ruffini E, Ferracini R, Roato I. Low dose of IL-12 stimulates T cell response in cultures of PBMCs derived from non-small cell lung cancer patients. J Cancer Ther 2012; 3:337-342.

19. Barygina V, Becatti M, Lotti T, Moretti S, Taddei N, Fiorillo C. Treatment with low-dose cytokines reduces oxidative-mediated injury in perilesional keratinocytes from vitiligo skin. J Dermatol Sci 2015;79:163-170.

20. Radice E, Miranda V, Bellone G. Low-doses of sequential-kinetic-activated interferon- $\gamma$ enhance the ex vivo cytotoxicity of peripheral blood natural killer cells from patients with early-stage colorectal cancer: a preliminary study. Int Immunopharmacol 2014;19:66-73.

21. Roberti ML, Ricottini L, Capponi A, Sclauzero E, Vicenti $P$, Fiorentini $E$, et al. Immunomodulating treatment with low dose interleukin-4, interleukin-10 and interleukin-11 in psoriasis vulgaris. J Biol Regul Homeost Agents 2014;28: 133-139.

22. Brod SA, Khan M. Oral administration of IFNalpha is superior to subcutaneous administration of IFN-alpha in the suppression of chronic relapsing experimental autoimmune encephalomyelitis. J Autoimmun 1996;9:11-20.

23. Avvakumov EG, Chizhevskaya SV, Stoyanov ES, Povetkina MV, Chekmarev AM, Shafirov VL, et al. Influence of the nature of components in mechanically activated mixture of zirconium and silicon oxides on solid-phase synthesis of zircon. Russ J Appl Chem 1999;72:1498-1503.

24. Dunn L, Prosser HC, Tan JT, Vanags LZ, Ng MK, Bursill CA. Murine model of wound healing. J Vis Exp 2013;28:e50265.

25. Das S, Singh G, Majid M, Sherman MB, Mukhopadhyay $S$, Wright CS, et al. Syndesome therapeutics for enhancing diabetic wound healing. Adv Healthc Mater 2016;5:2248-2260.
26. Jain AK, Tewari-Singh N, Inturi S, Orlicky DJ, White CW, Agarwal R. Histopathological and immunohistochemical evaluation of nitrogen mustard-induced cutaneous effects in SKH-1 hairless and C57BL/6 mice. Exp Toxicol Pathol 2014;66: 129-138.

27. Fairweather $M$, Heit $Y I$, Buie J, Rosenberg LM, Briggs A. Celecoxib inhibits early cutaneous wound healing. J Surg Res 2015;194:717-724.

28. Buszewska-Forajta M, Siluk D, Daghir-Wojtkowiak E, Sejda A, Staśkowiak D, Biernat W, et al. Studies of the effect of grasshopper abdominal secretion on wound healing with the use of murine model. J Ethnopharmacol 2015;176:413-423.

29. Miyamoto T, Nojima $H$, Kuraishi $Y$. Intradermal cholinergic agonists induce itch-associated response via M3 muscarinic acetylcholine receptors in mice. Jpn J Pharmacol 2002:88:351-354.

30. Khurana S, Shah N, Cheng K, Shiu B, Samimi R, Belo A, et al. Scopolamine treatment and muscarinic receptor subtype-3 gene ablation augment azoxymethane-induced murine liver injury. J Pharmacol Exp Ther 2010;333:639-649.

31. Pinto NC, Cassini-Vieira P, Souza-Fagundes EM, Barcelos LS, Castañon MC, Scio E. Pereskia aculeata Miller leaves accelerate excisional wound healing in mice. J Ethnopharmacol 2016;194:131-136.

32. Kampa M, Nistikaki A, Tsaousis V, Maliaraki N, Notas G, Castanas E. A new automated method for the determination of the total antioxidant capacity (TAC) of human plasma, based on the crocin bleaching assay. BMC Clin Pathol 2002;2:3-18.

33. Lattuada D, Uberti F, Colciaghi B, Morsanuto V, Maldi E, Squarzanti DF, et al. Fimbrial cells exposure to catalytic iron mimics carcinogenic changes. Int J Gynecol Cancer 2015;25:389-398.

34. Eming SA, Martin P, Tomic-Canic M. Wound repair and regeneration: mechanisms, signaling, and translation. Sci Transl Med 2014;6:265sr6.
35. Rajendran ES. Homeopathy as a supportive therapy in cancer. Homeopathy 2004;93:99-102.

36. Sunila ES, Kuttan R, Preethi KC, Kuttan G. Dynamized preparations in cell culture. Evid Based Complement Alternat Med 2009;6:257-263.

37. Witt CM, Lüdtke R, Willich SN. Homeopathic treatment of patients with psoriasis-a prospective observational study with 2 years follow-up. J Eur Acad Dermatol Venereol 2009;23:538-543.

38. Kho MM, Bouvy AP, Cadogan M, Kraaijeveld R, Baan CC, Weimar W. The effect of low and ultralow dosages Thymoglobulin on peripheral T, B and NK cells in kidney transplant recipients. Transpl Immunol 2012;26:186-190.

39. Kuwahara RT, Skinner RB, Rosenberg EW. Nicotine gum for oral lichen planus. J Dermatol 2000;27:755.

40. Klapproth H, Reinheimer T, Metzen J, Münch M, Bittinger $F$, Kirkpatrick $C J$, et al. Non-neuronal acetylcholine, a signalling molecule synthezised by surface cells of rat and man. Naunyn Schmiedebergs Arch Pharmacol 1997;355:515-523.

\section{Abbreviations and Acronyms}

$$
\begin{aligned}
\alpha 7 & =\text { nicotinic receptor } \\
\text { Ach } & =\text { acetylcholine } \\
\text { ANOVA } & =\text { analysis of variance } \\
\text { KC } & =\text { keratinocyte } \\
\text { M1 } & =\text { muscarinic type } 1 \text { receptor } \\
\text { M3 } & =\text { muscarinic type } 3 \text { receptor } \\
\text { M5 } & =\text { muscarinic type } 5 \text { receptor } \\
\text { MMP-9 } & =\text { matrix metalloproteinase } 9 \\
\text { NO SKA } & =\text { nonsequential kinetic activation } \\
\text { ROS } & =\text { radical oxygen species } \\
\text { SD } & =\text { standard deviation } \\
\text { SKA } & =\text { sequential kinetic activation } \\
\text { TMB } & =3,3^{\prime}, 5,5^{\prime} \text {-tetramethylbenzidine } \\
\text { VWF } & =\text { von Willebrand's factor } \\
W A & =\text { wound area } \\
\text { WA } & =\text { original size of the wound area }
\end{aligned}
$$

